\title{
УДК 004.738.5:37
}

Малицька Ірина Дмитрівна, старший науковий співробітник Інформаційноаналітичного відділу педагогічних інновацій Інституту інформаційних технологій i засобів навчання Академії педагогічних наук України

\section{ТЕНДЕНЦІЇ РОЗВИТКУ ГЛОБАЛЬНИХ ОСВІТНІХ МЕРЕЖ (ЗАРУБІЖНИЙ ДОСВІД)}

\section{Анотація}

У статті проаналізовані та визначені загальні тенденції розвитку глобальних освітніх мереж, використання їх ресурсів у системах освіти зарубіжних країн, подані приклади найпопулярніших серед освітян зарубіжних країн освітніх мереж.

Ключові слова: інформатизація освіти, освітній простір, глобальні освітні мережі.

Bcmyn. Аналіз сучасного стану систем освіти зарубіжних країн показує актуальність і необхідність існування, розвитку та створення інформаційних освітніх мереж - локальних, регіональних, глобальних, які стали невід'ємною частиною навчально-виховного процесу як в зарубіжних системах освіти, так і в нашій країні.

Глобальні мережі за останнє десятиріччя набувають все більшого значення, це ж стосується й систем освіти. Таким чином, перед сучасною наукою постало завдання вивчення використання ресурсів глобальних інформаційних освітніх мереж в освітніх процесах та пристосування їхніх можливостей та змісту до формування навчальновиховного процесу в загальноосвітній школі.

Метою статті є визначення загальних тенденцій розвитку глобальних освітніх мереж та використання їх ресурсів для подальшого їх застосування у системі освіти України.

Уміння користуватися ресурсами глобальних освітніх мереж стає все більш необхідним для освітян, учителів та учнів на всіх рівнях навчання в країнах зарубіжжя. Створення єдиного освітнього простору, якому вони сприяють, ускладнюється відмінностями в рівнях інформатизації та комп'ютеризації систем освіти, але процес інтеграції глобальних освітніх мереж у навчально-виховний процес загальної освітньої школи зарубіжжя стає все більш очевидним та неминучим.

Можна зазначити, що загальні тенденції розвитку використання глобальних освітніх мереж залежать від тієї освітньої політики, яку проводять системи освіти у своїх країнах. Пріоритети розвитку систем освіти, як показує практика, визначаються країнами зарубіжжя виходячи із законів, декларацій, документів, які створюють потужні міжнародні організації, такі як ООН, ЮНЕСКО, Рада Європи, Європейський 
Союз та інші.

Аналізуючи міжнародні закони, спрямовані на майбутній розвиток систем освіти країн світу, можна зазначити, що практично всі вони спрямовані та враховують глобальний розвиток суспільства, його вимоги, створення єдиного освітнього простору та приділяють велику увагу використанню IКТ, глобальних мереж зокрема.

Для освітян європейського простору одним з основних документів залишається Декларація у сфері розвитку європейської політики щодо використання новітніх інформаційних технологій. [7], затверджена у травні 1999 року Комітетом Міністрів Ради Свропи.

Як розвиток цієї Декларації у 2000 році країнами-членами ЮНЕСКО був прийнятий Дакарський план дій (Dakar Framework for action), який є одним з основних документів ЮНЕСКО, де визначені стратегії щодо розвитку систем освіти країн світу на період до 2015 року.

У цьому документі (Розділ 10 «Використання інформаційних та комунікаційних технологій для досягнення цілей, поставлених програмою Освіта для всіх») [6] зазначено, що інформаційно-комунікаційні технології (IКT) мають значний потенціал та їх необхідно використовувати для досягнення ефективності навчання, розповсюдження знань та розвитку більш ефективних освітніх послуг. Використання IКТ, особливо у країнах, що розвиваються, повинні бути поєднані 3 такими традиційними формами навчання, як книжки, радіо та велику увагу необхідно приділяти навчанню вчителів нових форм викладання предметів з використанням ІКТ.

Швидке розповсюдження ІКТ в освіті, уже зараз на практиці показує, що завдяки їх використанню можна подолати бар'єр різних культур, різного соціального стану, втілити у життя рівний доступ до освіти та отримання якісного навчання.

Крім цього, у документі зазначається велика роль IКТ у створенні баз даних, проведенні відповідних аналітичних звітів, укріпленні менеджменту освіти, починаючи з міністерств до локальних місцевих осередків.

Основні напрями розвитку освіти Російської Федерації визначені в урядовому документі «Концепція модернізації російської освіти на період до 2010 року», стверджують, що розвиток освіти не повинен відставати від світових тенденцій економічного та суспільного розвитку і проведення модернізації системи освіти 3 підвищенням ii якісного рівня, орієнтованого на світові досягнення, процеси глобалізації, є обумовленою необхідністю [13].

Головними напрямами державної інформаційної політики України (Закон України Про інформацію, стаття 6), яка безперечно має вплив на створення відповідних освітніх законів [8], визначені: 
- забезпечення доступу громадян до інформації;

- створення національних систем і мереж;

- зміцнення матеріально-технічних, фінансових, організаційних, правових i наукових основ інформаційної діяльності;

- забезпечення ефективного використання інформації та інші.

Подальший розвиток української системи освіти, його шляхи та напрями сформульовані в Законі України «Про Національну програму інформатизації» [9], яка сформована, «виходячи 3 довгострокових пріоритетів соціально-економічного, науково-технічного, національно-культурного розвитку країни з урахуванням світових напрямів розвитку та досягнень у сфері інформатизації і спрямована на розв'язання найважливіших загальносуспільних проблем (забезпечення розвитку освіти, науки, культури, охорони довкілля та здоров'я людини, державного управління, національної безпеки та оборони держави та демократизації суспільства), створення умов для інтеграції України у світовий інформаційний простір відповідно до сучасних тенденцій інформаційної геополітики».

Зважаючи на те, що основною первинною ланкою мережевого стану суспільства в цілому та систем освіти зокрема, є комп'ютер, у сучасних системах освіти як зарубіжних країн, так і в Україні, пріоритетними напрямами розвитку вже кілька десятиліть є інформатизація та комп’ютеризація освіти.

3 цією метою окреслене завдання зі створення індустрії сучасних засобів навчання, що відповідали б світовому науково-технічному рівню і які $є$ важливою передумовою реалізації ефективних стратегій досягнення цілей освіти та інформатизації освіти.

Українські вчені визначають термін інформатизація освіти як - у широкому розумінні - комплекс соціально-педагогічних перетворень, пов’язаних із насиченням освітніх систем інформаційною продукцією, засобами та технологією, у вузькому впровадження в заклади системи освіти інформаційних засобів, що грунтуються на мікропроцесорній техніці, а також інформаційної продукції і педагогічних технологій, які базуються на цих засобах. Інформатизація освіти (i. о.) - частина процесу інформатизації суспільства, теоретичною основою якого виступає інформатика система знань, яка стосується вироблення, переробки, зберігання, пошуку й поширення інформації в найрізноманітніших ii аспектах у природі, суспільстві, техносфері [29].

Без комп'ютеризації освіти, яка є складовою інформатизації, унеможливлюється процес розвитку та використання будь-яких освітніх глобальних мереж.

Процес комп'ютеризації набув цілеспрямованого характеру i 
загальнодержавного значення 3 часу розроблення i прийняття Концепції інформатизації освіти [14], який надалі був підтриманий Кабінетом Міністрів України Постановою від 7 грудня 2005 року №1053 Про затвердження державної програми «Інформаційні та комунікаційні технології в освіті і науці» на 2006-2010 pp.

Аналізуючи вищезазначені документи, можна стверджувати, що практично всі країни світу, високорозвинені та ті, що знедавна стали на шлях незалежного демократичного розвитку (наприклад, країни СНД) одними з пріоритетних напрямів у розвитку своїх систем освіти вбачають розвинуті інформаційно-комунікаційні технології та створення і роботу освітніх мереж різного масштабу та рівня.

У зв’язку зі створенням інформаційних супермагістралей, глобальних освітніх мереж (GINIE, GLORIAD, GlobalSchoolNet, Educared та інших) виникає необхідність проведення дослідження можливостей, виявлення тенденцій та особливостей глобальних інформаційних освітніх мереж у процесі розвитку та інтегрування їх у системи освіти світу з метою забезпечення сучасними інформаційними технологіями освітян України та доступу різних категорій користувачів до масивів банку даних освітньої інформації в рамках єдиного інформаційно-освітянського простору України та створення глобального освітнього простору.

Аналізуючи процес розвитку глобальних освітніх мереж можна зазначити, що цілі їх створення були практично однакові:

- обмін матеріалами та інформацією серед освітян різних країн;

- міжшкільний обмін;

- обмін досвідом між учителями-практиками, адміністраторами та політиками 3 метою визначення пріоритетних напрямів розвитку систем освіти.

Процеси глобалізації з часом розширювали рамки поставлених первинно задач та цілей, а також меж спілкування, які були окреслені під час створення самих мереж.

На початку 90-х років, коли доступ до мережі Інтернет був досить обмежений та ним могли користуватися тільки потужні міжнародні організації такі як Рада Європи, Європейський Союз, ООН, ЮНЕСКО та інші, мета створення мереж була у рамках компетенцій саме цих організацій, а розповсюдження їх можливостей на школи та в навчально-виховний процес було досить незначним.

Так, наприклад, створені на той час мережі EURYDICE (Інформаційна мережа 3 питань освіти Європейського Союзу), EUDISED (Європейські документаційні та інформаційні системи для освіти), CEDEFOP (Свропейський центр з розвитку професійної підготовки), ENIC Network (Європейська мережа національних інформаційних центрів) та інші практично видавали та розповсюджували матеріали досліджень, які не завжди швидко надходили, але мали справді вагоме значення для 
вчителів-практиків. Незадовільний рівень комп'ютеризації систем освіти та їх доступу до Інтернету ускладнював роботу з ними та, з огляду на це, вони не мали значного впливу на формування навчально-виховного середовища у навчальних закладах.

Найпростішою ідеєю використання мереж безпосередньо у школах було здійснення обміну досвідом через мережі (завдяки мережі Інтернет) та спілкування між школярами різних країн, розвиваючи в них інтеркультурні та лінгвістичні навички.

Розширення можливостей мереж та охоплення ними все більшої кількості шкіл у різних куточках світу змінило та постійно змінює критерії щодо їх використання у загальноосвітніх навчальних закладах (ЗН3). Спостерігається їх швидка інтеграція у навчально-виховний процес.

Критерії щодо використання мережних технологій, а саме ресурсів глобальних освітніх мереж, у школах зарубіжжя (досвід Свропи, Америки та Росії) можна означити як:

- змістовність мереж,

- актуальність інформації, якою вони наповнюються,

- доступність та відкритість щодо її отримання,

- корисність та доцільність щодо використання таких мереж у формуванні навчально-виховного процесу в ЗНЗ.

Усе це уможливлюється завдяки використанню та на базі мережі Інтернет, яка залишається до цього часу самою розповсюдженою інформаційно-комунікаційною технологією, що постійно та дуже швидко розвивається та вдосконалюється.

Усе більша іï відкритість та доступність надає такі ж самі можливості у формуванні нових та використанні вже існуючих інформаційних освітніх мереж.

Процеси глобалізації призводять до перетворення вже існуючих та діючих регіональних, національних мереж у глобальні. Не обійшов він й інформаційні освітні мережі. Залишаючись більш конкретно спрямованими, вони розширюють межі своїх користувачів охоплюючи та відповідаючи на сучасні виклики суспільства.

Інтеграційні процеси розширили кордони для отримання освіти та роботи. Уже виникає необхідність визначення або навіть прогнозування вимог щодо навичок, умінь та компетентностей, якими необхідно володіти та які визначаються у свою чергу вимогами ринку праці окремої країни та є актуальними, наприклад, на європейському, а може й на світовому ринку праці.

Формування механізму прогнозування, моніторингу та державного регулювання підготовкою спеціалістів відповідно потреб ринку праці, освіта впродовж життя стали 
нагальною потребою більшості країн світу.

3 цією метою у структурі мережі CEDEFOP (European Centre for the Development of Vocational Training - Свропейський центр із розвитку професійної підготовки), яка була визначена як європейська освітня мережа, у 2004 році була створена мережа Skillsnet (Мережа вмінь та навичок), яка охопила 120 країн світу різних цільових груп, постійно розширює рамки своєї діяльності і поступово, можна сказати, перетворюється на глобальну мережу [15].

До Skillsnet входять висококваліфіковані дослідники та представники освіти 3 усього світу. Вони представляють на розгляд, обговорюють та аналізують результати та методи досліджень з ідентифікації умінь та навичок, що змінюються відповідно часу та вимог ринку праці, а також прогнозують довгострокові перспективи щодо нових умінь та навичок, які будуть потрібні на ринку праці через деякий час.

Перш ніж отримати та систематизувати відповідну інформацію проводяться дослідження та аналіз на національному, регіональному, секторному та професійному рівнях, а також аналіз потреб у відповідних навичках певних цільових груп, як, наприклад, рівень низької або високої кваліфікації. Підходи переважно включають підприємство і огляди робочої сили на різних рівнях, передбачаючи методи, приклади для вивчення, аналіз та рекламу роботи, досвідчені запити, сценарії з питань визначення необхідності відповідних навичок та вмінь. Схожість проведення таких обстежень, їх методів та схожість у потребах у відповідних навичках та вміннях допомагають ідентифікувати загальні європейські або міжнародні тенденції у вимогах до отримання відповідних навичок та вмінь. Приклади - туризм, логістика і нові технології (наприклад біотехнологія, енергетика, і т. п.). Пріоритет надається цілісним підходам та інноваційним рішенням у проведенні дослідження й аналізу, який може проводитися в проміжку часу між фактичною зміною в політиці та обранню напряму розвитку економіки. Отриманні результати надаються політикам та адміністраторам 3 освіти з метою проведення відповідних реформ, до яких необхідно залучати різні державні структури.

До постійної діяльності мережі входить проведення тематичних семінарів, що організуються в співпраці з членами мережі, загальних проектів, конференцій, що проводяться двічі на рік. Члени мережі проводять узгодження та розгляд методологічних підходів та одержаних даних через електронну платформу, яка забезпечується командою Cedefop.

Мережа забезпечує форум поколінь нових дій та проектів з ідентифікації вмінь та навичок на ранній стадії через інтеграційні процеси між середнім та іншими рівнями освіти. Результати обговорюються з політиками з освіти, юристами, службами 
зайнятості та соціальними службами, які працюють в напрямку ідентифікації вмінь та навичок з метою надання висновків та пропозицій в міністерство освіти для подальшого практичного застосування, починаючи з упровадження їх у навчальновиховний процес ЗНЗ.

Змістовність мереж має первинне значення для їх використання у навчальновиховному процесі загальної середньої школи країн зарубіжжя. Розглянемо декілька прикладів використання глобальних інформаційних освітніх мереж у школах різних країн.

Однією з найвідоміших серед учителів та учнів світу є глобальна освітня мережа Global SchoolNet (GSN) [4], започаткована в 1984 році завдяки проекту двох учителів, які завдяки електронній пошті розпочали спілкування учнів двох шкіл, які знаходилися на далекій відстані одна від одної. Згодом цей проект розширив свої рамки від двох до 45000 шкіл із 194 країн світу та залучив до спілкування більш ніж 90000 освітян з усього світу.

Головною метою мережі є втілення у життя напряму освіти впродовж життя.

Ïї робота, яка спрямована на навчання методом проектів, проблемно-орієнтоване навчання та он-лайн навчання. Основними цілями роботи мережі $\epsilon$ визначення спільних потреб учнів із різних куточків світу, які б відповідали перспективам глобального розвитку та допомагали їм стати відповідальними та освіченими громадянами світу.

Популярними серед учнів та вчителів $є$ такі проекти як:

- Кібер-ярмарка 2007 - міжнародне навчання для дітей віком від 5 до 19 років, які таким чином створюють свою локальну навчаючу спільноту;

- Веб-проект «Двері дипломатії» - інтеркультурне виховання, навички міжнародного співробітництва;

- Програма «Світ шаленого Біллі» - спрямована на отримання навичок читання, писання та використання цифрових медіа у процесі навчання;

- Он-лайн Експедиції - інтерактивні уроки з історії;

- ео-гра - географія - з вивченням карт (триває з 1991 року);

- Журналістика - створення спільної інтернет-газети (навички письма, спільної співпраці тощо);

- Листівки до Санти - один із перших проектів, який існує з 1985 року для молодших школярів (розвиток навичок письма).

Проводиться постійна підтримка вчителів інформаційними матеріалами та відповідними Інтернет-ресурсами. Щорічно мережею проводиться конкурс серед учителів, які найбільш вдало та активно використовують телекомунікаційні технології 
у навчальному процесі та заохочують до нього якомога більше учнів, беручи до уваги інтеркультурний аспект.

Глобальна освітня мережа HappyChild (HappyChild) [5], яка спрямована на допомогу дітям, особливо молодшого шкільного віку, використовує метод проектів, он-лайн навчання, форуми та чати.

Створена база даних із різних шкіл, університетів та навчальних закладів 3 усього світу надає можливість спілкування між учнями та вчителями, втілюючи у життя інтеркультурні навички.

Он-лайн ресурс надає можливість отримати базові навички 3 вивчення іноземних мов, наприклад читання англійською мовою - починаючи 3 фонетики, вивчаючи граматику, читання, письмо та складання віршів i розповідей через можливість інтерактивного спілкування як із своїми однолітками, так і з учителями.

На сайтах мережі існують он-лайн уроки 3 математики, природничих наук, географіï.

Однією 3 найпоширеніших та популярних освітніх іспаномовних мереж $\epsilon$ мережа EducaRed [12], яка об’єднує освітян, адміністраторів, науковців, політиків 3 освіти, учнів та вчителів, батьків. Інструментами мережі $є$ проведення он-лайн уроків, проектів, семінарів, конференцій та форумів із різних тем та освітніх проблем. Завдяки мережі створюються та працюють віртуальні спільноти вчителів (за різними предметами та інтересами), учнів (за різними інтересами), батьків та науковців.

Розповсюдження знань із різних предметів, практично надаючи дистанційне навчання, надає одна 3 найбільш відомих освітніх глобальних мереж у країнах Латинської Америки та країнах Карибського басейну є мереж Red Global de Apredizaje para el Dessarrollo (Global Development Learning Network (GDLN) - Навчаюча мережа 3 глобального розвитку [17]. У своїй роботі вона використовує теле-відео-інтернет дебати, відеоконференції, семінари та конференції, створення інформаційних центрів. Важливим здобутком мережі $\epsilon$ можливість отримання сертифікатів, визнаних міжнародними університетами та Світовим банком, які отримують студенти після закінчення навчальних курсів та програм, запропонованих мережею.

Загальноосвітня школа, яка є базовою ланкою освіти, підлягає модернізації, орієнтованій не тільки на те, щоб учень отримав необхідну кількість знань, але й на розвиток його особистості, його пізнавальних і творчих здібностей, а також вона повинна бути спрямована на формування цілісної системи універсальних знань, умінь, навичок.

Визнаючи важливість розвитку в учнів креативного мислення, уміння знаходити та вилучати необхідну інформацію 3 метою проведення самостійних наукових 
досліджень в процесі навчання, особливе місце в системах освіти зарубіжних країн займає створення науково-інформаційного простору, насамперед для дітей та молоді з використанням для цього нових комунікаційно-інформаційних засобів.

Таким прикладом може слугувати глобальна освітня мережа Xplora [2], яку називають Європейськими воротами до наукової освіти, вона об'єднує учнів, учителів та науковців, надає можливість ознайомитись з новинами, педагогічними винаходами, інноваційними ідеями для вчителів стосовно наукової освіти; проводити пошук по базах даних та різних електронних джерелах; брати участь в семінарах та конференціях у режимі он-лайн; ознайомитись 3 інноваційними напрямами та проектами; використовувати різноманітні інформаційно-комунікаційні технології, які розміщені в мережі безкоштовно.

До основної наукової групи мережі увійшли вчителі, які мають свій власний інноваційний педагогічний підхід, високий рівень компетентності у використанні інструментів ІКТ та здатні ефективно співпрацювати з міжнародним співтовариством.

Проекти, ініційовані мережею, мають на меті охопити всі рівні навчання, починаючи з початкового та об'єднати у своїй роботі не тільки школи, але й державні й недержавні установи, створюючи таким чином науково-дослідницькі осередки за різними напрямами. Зараз успішно проводяться проекти з хімії, природничих наук у початковій школі, техніки, електроніки, телекомунікаційних технологій, біотехнології, прикладної математики та інші.

Існуюча з 2004 року науково-освітня мережа GLORIAD [3] має на меті накопичення та розповсюдження досвіду ведення наукової діяльності, який здійснюється через форуми, мережу Інтернет, проведення міжнародних аудіо- та відеоконференцій та семінарів. Практичним виходом роботи мережі $є$ створення глобального співтовариства, яке обговорює, розробляє та сприяє втіленню не тільки у сферах енергетики, астрономії, фізики, ядерної фізики, геології, також створює спільну, віртуальну класну кімнату для студентів, які, використовуючи новітні інформаційно-комунікаційні технології (відео сесії, аудіо- та відеоконференції, форуми та чати) мають можливість не тільки співпрацювати, але й навчатися в онлайн режимі.

У Росії значно відрізняється від інших освітніх мереж на теренах цієї країни Глобальна Російська освітня мережа REDLINE [1], яка розпочала свою роботу у червні 1994 року та була заснована Міністерством Освіти Росії та $є$ некомерційною структурою.

Головним завданням мережі $є$ збір, аналіз та обробка освітньої інформації, створення бази даних, проведення телеконференцій через мережу Інтернет. 
До створеного банку даних входить інформація, яка стосується різних сфер та напрямів системи освіти Росії, включаючи адміністративні та фінансові питання. Акумульована наукова педагогічна інформація. Проект створення мережі спонсорується Урядовою Організацією США для міжнародного розвитку та Американським Фондом "СвроАзія" маючи за мету створення глобального банку даних із питань та напрямів систем освіти. Створюючи глобальний банк даних велика увага приділяється накопиченню та систематизації педагогічної інформації, яка може бути доступною широкому колу зацікавлених.

Але найбільш діючим та популярним залишається портал Російської Федерації «Интернет-образование» [24], на базі якого не тільки існує величезна база даних із вивчення та використання ІКТ в освіті, бібліотека, постійнодіючий журнал «Інтернетосвіта», курси дистанційного навчання, але й створюються та інтерактивно діють віртуальні осередки як учителів, так і учнів, поступово перетворюючись у глобальні освітні мережі.

Дуже популярним та відомим у Росії є Загальноосвітній портал [26], до змісту якого входить освітня інформація, надана Російським Міністерством освіти та науки. Практично це зібрана база даних із невеликим інтерактивним спілкуванням.

В Україні схожим на цей портал можна назвати Український портал «Освіта України» - http://www.edu-ua.net/ukr/osvita/.

Такі освітні портали на цей час уже не відповідають вимогам часу та потребам освітян. Вони досить статичні, інформація оновлюється невчасно та немає інтерактивного спілкування і можливостей проведення конференцій або семінарів онлайн.

На теренах як України, так і Росії практично діє єдина глобальна освітня мережа «IEARN» [16], яка створює єдиний освітній простір як для учнів, так і для вчителів, навчає їх новим інформаційним комунікаційним технологіям, проводячи освітні проекти.

Висновки. Аналізуючи вищезазначене, можна констатувати, що спостерігається стійка тенденція щодо інтегрування використання IКТ (глобальних освітніх мереж зокрема) у все більшу кількість предметів загальної середньої школи. Ресурси та можливості глобальних освітніх мереж допомагають знайти різноманітні форми та засоби, завдяки яким уможливлюється викладання предмета у найбільш цікавій, сучасній формі, допомагають вчителям-практикам ознайомитися та впроваджувати інновації, підвищувати свою професійну кваліфікацію, обмінюватися досвідом (Global School Network, Community Learning Network, Happy Child, EducaRed, IEARN).

Найбільш розповсюдженою тенденцією щодо використання глобальних мереж, 
яка постійно набуває все більш широкого розповсюдження, залишається проектна діяльність, яка все більш фокусується не тільки на об’єднанні учнів, учителів, освітян в робочі групи для здійснення конкретного проекту, а на надання їм навичок, які б відповідали вимогам глобального суспільства та навчили їх письменності XX1-го століття.

Ще однією тенденцією розвитку глобальних освітніх мереж $є$ створення віртуальних осередків: учнів, учителів та освітян (Global School Network, Happy Child, EducaRed), учнів, учителів та науковців (Community Learning Network, EducaRed, Global Knowledge Partneship, GLORIAD), учителів-новаторів та науковців (Community Learning Network, EducaRed).

Проведений порівняльний аналіз щодо особливостей використання ресурсів глобальних мереж у системах освіти в Україні та зарубіжних країнах (країнах Свропи, Америки та Росії) показав:

- починаючи 3 початку XX1-го століття, особлива увага, визнання та значна підтримка розвитку ІКТ, інформаційних освітніх регіональних та глобальних мереж приділяється практично всіма країнами світу, що закріплено відповідними політичними документами, законами та деклараціями, які спрямовані на активні практичні дії з урахуванням процесів глобалізації;

- використання інформаційних комунікаційних технологій, до яких належать глобальні інформаційні мережі, стає характерною ознакою систем освіти зарубіжних країн. Розширюються можливості та діапазон використання глобальних інформаційних мереж у загальноосвітніх школах: від просто інтерактивного спілкування, обміну досвідом та електронної пошти до створення своїх сайтів, порталів та мереж. Крім того, все більшу розповсюдженість набуває система відкритого он-лайн навчання, отримання дипломів та сертифікатів в режимі он-лайн, віртуальні школи та університети.

У країнах зарубіжжя (Свропи, Америки та Росії) та в Україні основні принципи та критерії щодо використання ресурсів глобальних освітніх мереж у загальній середній школі практично співпадають. Їх можна означити як змістовність мереж, актуальність інформації, якою вони наповнюються, доступність та відкритість щодо іiі отримання, корисність та доцільність щодо використання таких мереж у формуванні навчально-виховного процесу у загальній середній школі.

Відрізняються підходи щодо використання глобальних освітніх мереж. Для країн зарубіжжя є характерним не тільки просто вилучення інформації та обмін досвідом, але й проведення он-лайн уроків та отримання освіти.

В Україні підходи щодо використання освітніх глобальних мереж у загальній 
середній школі звужуються до участі у проектній діяльності (мережа «IEARN»), надаючи можливість учням розширити свої знання 3 деяких предметів (англійська мова, географія, історія тощо) або вони використовуються на уроках інформатики, завдяки чому надається можливість отримати та розширити, завдяки обміну досвідом 3 учнями 3 інших країн світу, знання та вміння 3 таких напрямів інформаційних технологій як веб-дизайн, інженерне проектування, програмування тощо. Та менш за все використовуються такі мережі у професійній освіті та підготовці педагогічних кадрів, які займають основне місце у формуванні та розвитку освітнього середовища загальної середньої школи.

Зважаючи на повільні темпи інформатизації системи освіти України, невеликої кількості шкіл, які підключені до Інтернету та низькому рівню знань 3 комп’ютерної та Інтернет грамотності вчителів-практиків, можна зазначити, що освітяни України активно працюють та розширюють поле своєї діяльності у глобальній мережі IEARN, яка розвивається згідно із загальними тенденціями розвитку глобальних освітніх мереж, зазначених вище. На даному етапі розвитку системи освіти України виникає нагальна потреба якнайшвидше допомогти освітянам, особливо вчителям-практикам, оволодіти інформаційно-комунікаційними технологіями для їх використання у своїй повсякденній практиці.

\section{Список використаних джерел}

1. Глобальна Російська освітня мережа. - [Електронний ресурс]. - Режим доступу: http://www.redline.ru/ - заголовок з екрану.

2. Глобальна освітня мережа Xplora. - [Електронний ресурс]. - Режим доступу: http://www.xplora.org/ww/en/pub/xplora/hands_on_brains_on.htm. - Заголовок з екрану.

3. Глобальна мережа GLORIAD. - [Електронний ресурс]. - Режим доступу: http://www.gloriad.org/gloriad/index.html. - Заголовок з екрану.

4. Глобальна шкільна мережа Global School Network. - [Електронний ресурс]. Режим доступу: http://www.globalschoolnet.org/index.html. - Заголовок з екрану.

5. Глобальна освітня мережа НарpyChild. - [Електронний ресурс]. - Режим доступу: http://www.happychild.org/. - Заголовок з екрану.

6. Дакарський план дій (Dakar Framework for action). - [Електронний ресурс]. Режим доступу:http://www.unesco.kz/education/efa/dfa_eng.pdf. - Заголовок з екрану.

7. Декларація в сфері розвитку європейської політики стосовно використання новітніх інформаційних технологій - Портал Ради Свропи. - [Електронний ресурс]. Режим доступу: http://www.coe.int/. - Заголовок з екрану.

8.Закон України Про інформацію. - [Електронний ресурс]. - Режим доступу: http://www.ucrf.gov.ua/uk/doc/laws/1149672211/. - Заголовок з екрану. 
9. Закон України «Про Національну програму інформатизації».- [Електронний pecypc] - Режим доступу:http://osvita.org.ua/distance/pravo/08.html. - Заголовок 3 екрану.

10. Законодавство України про інформацію// Бюлетень законодавства i юридичної політики України. - 1998. - №7. - С. 8-272.

11. Інформатизація і комп'ютеризація загальноосвітніх навчальних закладів України - 2- років /А.М. Гуржій, В.Ю. Биков, В.В. Гапон, М.Я. Плескач// Комп’ютер у школі та сім’ї. - 2005. - №5. - С. 3-11.

12. Іспанська освітня мережа EducaRed. - [Електронний ресурс]. - Режим доступу: http://www.educared.net/. - Заголовок з екрану.

13. Концепція модернізації російської освіти на період до 2010 року. [Електронний ресурс]. - Режим доступу: http://www.edu.ru/db/mo/Data/d_02/393.html. Заголовок з екрану.

14. Концепція програми інформатизації загальноосвітніх навчальних закладів, комп'ютеризації сільських шкіл/ В.О. Огнев'юк, В.Ю. Биков, М.І. Жалдак та ін.// Комп’ютер у школі та сім'ї. — 2000. — №3. - C. 3-10.

15. Мережа Skillsnet. - [Електронний pecypc]. - Режим доступу: http: // www.trainingvillage.gr/etv/Projects_Net works/Skillsnet/intro.asp). - Заголовок з екрану.

16. Міжнародна освітня та ресурсна мережа «IEARN». - [Електронний ресурс]. - Режим доступу:http://www.iearn.org.ua/index.html. - Заголовок з екрану.

17. Навчаюча мережа $з$ глобального розвитку (Red Global de Apredizaje para el Dessarrollo). - [Електронний pecypc]. - Режим доступу: http://alc.gdln.org/guarare/. Заголовок з екрану.

18. Національна доктрина розвитку освіти, розділ IX «Інформаційні технології в освіті»», п. 19). - [Електронний ресурс]. - Режим доступу: http://www.mon.gov.ua/laws/Ukaz_Pr_347.doc. - Заголовок з екрану.

19. Операційні системи та мережі шкільних комп'ютерних комплексів: Навч. посіб. для слухачів системи підвищ. кваліфікації /В.Ю. Биков, В.Д. Руденко; Ін-т систем дослідж. освіти України, Укр. ін-т підвищ. кваліфікації керів. кадрів освіти. К.: Компас, 1993 - 279 с.

20. Основи нових інформаційних технологій навчання: Посібник для вчителів /Авт. кол.; За ред. Ю.І. Машбиця /Інститут психології ім. Г.С. Костюка АПН України. -К.: ІЗМН, 1997. - 264 с.

21. Партнерство з отримання глобальних знань GKP (Global Knowledge Partnership). - [Електронний pecypc]. - Режим доступу: http://www.globalknowledge.org/. - Заголовок з екрану. 
22. Проект Дескартес. - [Електронний ресурс]. - Режим доступу: http://descartes.cnice.mecd.es/ingles/presentacion/Proyecto\%20Descartes\%20 (presentacion).htm. - Заголовок з екрану.

23. Російський портал Інтернет-освіти. - [Електронний ресурс]. - Режим доступу: http://dictionary.fio.ru/article - Заголовок з екрану.

24. Російська Федерація «Интернет-образования». - [Електронний ресурс]. Режим доступу:http://www.fio.ru/. - Заголовок з екрану.

25. Російська федерація дистанційної освіти. - [Електронний ресурс]. - Режим доступу: http://tmn.fio.ru/works/01x/306/. - Заголовок з екрану.

26. Російський загальноосвітній портал. - [Електронний ресурс]. - Режим доступу: http://www.school.edu.ru. - Заголовок з екрану.

27. Спільнота навчаючої мережі (CLN) Community Learning Network. [Електронний ресурс]. - Режим доступу: http://www.cln.org/index.html. - Заголовок 3 екрану.

28. Українська освітня мережа (Educational Network Ukraine). - [Електронний pecypc]. - Режим доступу:http://www.ednu.kiev.ua. - Заголовок з екрану.

29. Український педагогічний словник. /Семен Гончаренко. - Київ: Либідь, 1997. - $376 \mathrm{c}$.

30. Электронные компоненты информационно-образовательной среды. Российский портал открытого образования. -В.А. Красильникова, П.В. Веденеев, А.С. Заварихин, Т.Н. Казарина. - [Електронний ресурс]. - Режим доступу: http://www.openet.ru. - Заголовок з екрану.

\section{ТЕНДЕНЦИИ РАЗВИТИЯ ГЛОБАЛЬНЫХ ОБРАЗОВАТЕЛЬНЫХ СЕТЕЙ (ЗАРУБЕЖНЫЙ ОПЫТ)}

\section{Малицкая И.Д.}

\section{Аннотация}

В статье проанализированы и определены общие тенденции развития глобальных образовательных сетей, использование их ресурсов в системах образования зарубежных стран, приведены примеры наиболее популярных образовательных сетей.

Ключевые слова: информатизация образования, образовательное пространство, глобальные образовательные сети.

\section{TENDENCIES OF DEVELOPMENT OF GLOBAL EDUCATIONAL NETWORKS (FOREIGN EXPERIENCE)




\section{Resume}

In the article the general tendencies of development of global educational networks, use of their resources in education systems of foreign countries are analyzed. The examples of the most popular educational nets are presented.

Keywords: informatization of education, educational environment, global educational nets. 